\title{
A Case Report of Obstructive Sleep Apnea Syndrome Admitted to the Hospital with Chronic Cough
}

\author{
Kronik Öksürük ile Başvuran Obstrüktif Uyku Apne Sendromu Olgusu
}

Selvi Aşker, ${ }^{1}$ Müntecep Aşker ${ }^{2}$

\begin{abstract}
Obstructive Sleep Apnea Syndrome is characterized by recurrent upper respiratory tract obstruction episodes during sleep. The aperture of the upper respiratory tract during sleep depends on the equilibrium between the collapsing effect of the negative pressure that occurs within the pharyngeal lumen during inspiration, and the powers that maintain the aperture of the upper respiratory tract. Obstructive sleep apnea syndrome with chronic cough is a rare situation. These two symptoms together make the patient feel more dyspneic both in sleep and awake states. In cases of incurable cough, obstructive sleep apnea syndrome should be considered. The current study presents a case of chronic cough, which was not cured despite appropriate treatment and displayed REM-induced sleep apnea in polysomnography.
\end{abstract}

Key words: Chronic, cough, obstructive sleep apnea syndrome.

\section{Özet}

Obstrüktif uyku apne sendromu uyku sırasında tekrarlayan üst solunum yolu obstrüksiyonu epizotları ile karakterize bir sendromdur. Uykuda üst solunum yolu açıklığı inspiryum esnasında faringeal lümen içinde oluşan negatif basıncın kollabe edici etkisi ile üst solunum yolunu açık tutmaya çalışan güçlerin dengesine bağlıdır. Obstrüktif uyku apne sendromunun öksürük semptomu ile birlikte görülmesi nadir rastlanan bir durumdur. Bu iki tablonun bir arada bulunması ise hem uykuda, hem uyanıklıkta solunum sıkıntısının daha fazla hissedilmesine neden olmaktadır. Tedavi edilemeyen kronik öksürük vakalarında obstrüktif uyku apne sendromu düşünülmelidir. Bu çalışmada uygun tedaviye rağmen klinik düzelme sağlanamayan ve polisomnografide rem ilişkili obstrüktif uyku apnesi saptanan bir kronik öksürük olgusu sunulmaktadır.

Anahtar Sözcükler: Kronik, öksürük, obstrüktif uyku apne sendromu.
${ }^{1}$ Department of Chest Disease, Van Yüksek Ihtisas Training and Research Hospital, Van, Turkey

${ }^{2}$ Department of Cardiology, Van Yüksek Ihtisas Training and Research Hospital, Van, Turkey
`Van Yüksek Ihtisas Eğitim ve Araştırma Hastanesi, Göğüs Hastalıkları Bölümü, Van

${ }^{2}$ Van Yüksek Ihtisas Eğitim ve Araştırma Hastanesi, Kardiyoloji Bölümü, Van

Submitted (Başvuru tarihi): 10.12.2012 Accepted (Kabul tarihi): 15.02.2013

Correspondence (iletişim): Selvi Aşker, Department of Chest Disease, Van Yüksek Ihtisas Training and

Research Hospital, Van, Turkey

e-mail: selviasker@mynet.com

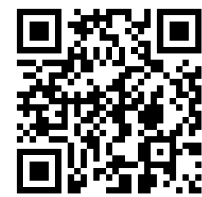


Obstructive sleep apnea syndrome (OSAS) is characterized with episodes of complete (apnea) or partial (hypopnea) upper airway obstruction and frequent decrease in blood oxygen saturation (1). Sleep apnea syndrome affects $4 \%$ of men and $2 \%$ of women. It is an important disease that has been shown to have a close association with obesity and a progressively increasing severe health problem (2). A significant increase in resistance develops in the upper airways, especially in the upper part of the larynx. The increase in resistance particularly occurs in the palate and the hypopharynx (3).

Obstructive sleep apnea patients present to the outpatient clinic with complaints of snoring at night, sleepiness in the daytime and witnessed apnea. The complaint of chronic cough is rare. Chronic cough is a defined as a cough that lasts more than 8 weeks. These patients are those who have been followed-up with the diagnosis of upper airway diseases, gastroesophageal reflux, or cough-related asthma, but have not benefited from the treatment. The coexistence of obstructive sleep apnea syndrome and asthma is rare. Coexistence of these two diseases leads to the feeling a higher degree of respiratory distress during both sleep and arousal.

The gold standard method for the diagnosis of OSAS is polysomnography (PSG). The stages of sleep and various physiological parameters are recorded during sleep with the polysomnography method (4). The current study presents a case of cough-related OSAS, which was diagnosed with cough-related asthma at the institution to which the patient was admitted with the complaints of dyspnea, wheezing, and nocturnal cough for three years, and did not benefit from long-term treatment. The initiation of CPAP not only resulted in the resolution of sleep apneas and hypopneas, but also in the resolution of the chronic cough.

\section{CASE}

A 31-year-old female patient presented to various institutions with complaints of exertional dyspnea, wheezing, and nocturnal cough for three years. Her complaints did not improve although she used inhaler corticosteroids, beta-mimetic inhaler devices, oral montelukast and theophylline with the diagnosis of asthma.
The physical examination showed that the patient was $160 \mathrm{~cm}$ tall and had a body weight of $60 \mathrm{~kg}$ and a body mass index of $23.4 \mathrm{~kg} / \mathrm{m}^{2}$; arterial blood pressure was 120/75 mmHg, pulse was 95 bpm, respiratory rate was $25 / \mathrm{min}$, and she had tachypnea. On respiratory system examination, there were inspiratory rhonchi in all lung fields. Other system examinations were normal.

Laboratory examinations were normal except for a mild anemia (Hb 11.2 gr). Chest X-Ray, respiratory function tests, bronchoscopic tests, and transthoracic echocardiography of the patient revealed normal results.

The patient, who had received full and sufficient asthma treatment, was questioned in particular about the use of an inhaler device. It was learnt that she had used inhaler devices regularly with the correct technique. The patient had not recovered despite full and regular drug use and the correct device use was re-evaluated. The inspiratory rhonchi were found to be more prominent and in the stridor pattern.

The patient was considered to have an upper airway obstruction. Computed tomography (CT) of the thorax and paranasal sinuses and magnetic resonance imaging (MRI) of the neck, which were obtained to reveal this, were normal. On ear-nose-throat and laryngoscopy examinations, the upper airway was normal. The patient was evaluated by the gastroenterology department and confirmed not to have gastroesophageal reflux by abnormal 24-hour esophageal pH study.

The Muller maneuver was performed during bronchoscopy to reveal tracheal collapse; however, collapse was not detected. The patient underwent the polysomnography test (Embla 4500) due to marked nocturnal symptoms. Nocturnal symptoms were snoring and cough. The apnea-hypopnea index (AHI) was determined as 18.8/h throughout the night and 57/h during REM sleep. With these findings, the patient was diagnosed with REM-associated OSA. Apnea disappeared at $9 \mathrm{cmH}_{2} \mathrm{O}$ pressure with automatic CPAP (continuous positive airway pressure) treatment. Nocturnal symptoms completely disappeared and diurnal symptoms decreased. All treatments were discontinued after continuing asthma treatment for two additional months. The patient's physical examination findings were normal on routine controls, and she was followed-up with only the APAP 
(automatic positive airway pressure) device without drug therapy.

\section{DISCUSSION}

Obstructive sleep apnea syndrome is characterized by recurrent hypoxemia during sleep and episodes of upper airway obstruction leading to sleep disorder. There is an association between obstructive sleep apnea syndrome and many clinical conditions. In some cases, sleep apnea is the primary pathology and it is only a finding of the related disease in others (4). Obstructive sleep apnea patients present to the outpatient clinic with complaints of snoring during sleep, extreme somnolence in the daytime, and witnessed apnea. Recent studies have indicated that OSA is a syndrome associated with airway inflammation and some OSA patients presented with the complaint of a cough $(5,6)$. Recurrent upper airway obstruction may lead to reflex bronchoconstriction by stimulating the neural receptors in the pharynx of patients; hence, a portion of the OSA patients present with symptoms of bronchus hyperreactivity and bronchitis $(5,7)$. Inflammatory diseases such as asthma and COPD were seen to recover when OSA was treated $(8,9)$. The association of asthma and OSA symptoms has been shown in some clinical studies. In some of these studies, the incidence of OSA was found to be high in asthma patients who snored (10-12).

Upper airway diseases, gastroesophageal reflux and cough-related asthma are the first considered diseases in patients who have complaints of chronic cough. OSA should also be considered in the presence of a cough for which no other causes can be found or which is resistant to therapy. Chan et al. (13) found improvement in the inflammatory markers and nocturnal symptoms, and a decrease in the need for bronchodilator drugs with CPAP treatment. CPAP treatment would be effective for relief of cough by decreasing the inflammation in these patients (14).

We consider that the polysomnography test should be performed in chronic cough cases, which are very frequent despite the lack of sufficient data in the literature. We consider that this case report will be beneficial as it indicates that a disease like OSAS, which causes inflammation and obstruction in the airways, should be considered in patients who have been prediagnosed with asthma due to a chronic cough and treated for a long period of time, and who have normal radiological findings, but who have not obtained any favorable response.

\section{CONFLICTS OF INTEREST}

None declared.

\section{REFERENCES}

1. American Academy of Sleep Medicine. ICSD- The International Classification of Sleep Disorders. Diagnostic and Coding Manual, 2nd ed. Westchester, Illinois: AASM, 2005.

2. Young T, Palta M, Dempsey J, Skatrud J, Weber S, Badr $\mathrm{S}$. The occurrence of sleep-disordered breathing among middle-aged adults. N Engl J Med 1993; 328:1230-5. [CrossRef]

3. Hudgel DW, Hendricks C. Palate and hypopharynx-sites of inspiratory narrowing of the upper airway during sleep. Am Rev Respir Dis 1988; 138:1542-7. [Cross$\underline{\text { Refl }}$

4. Köktürk O. Obstrüktif uyku apne sendromu klinik özellikleri. Tüberküloz ve Toraks Dergisi 1999; 47:117-26. [CrossRef]

5. American Academy of Sleep. Sleep-related breathing disorders in adults: recommendations for syndrome definition and measurement techniques in clinical research; the report of an American Academy of Sleep Medicine Task Force. Sleep. 1999; 22:667-89.

6. Sundar KM, Daly SE, Pearce MJ, Alward WT. Chronic cough and obstructive sleep apnea in a communitybased pulmonary practice. COUGH 2010; 6:2. [CrossRef]

7. Salerno FG, Carpagnano $E$, Guido $P$, Bonsignore $M R$, Roberti $A$, Aliani $M$, et al. Airway inflammation in patients affected by obstructive sleep apnea syndrome. Respir Med 2004; 98:25-8. [CrossRef]

8. Larsson LG, Lundback B, Jonsson E, Lindberg A, Sandstrom T. Are symptoms of obstructive sleep apnea syndrome related to bronchitic symptoms or lung function impairment? Report from the Obstructive Lung Disease in Northern Sweden study. Respir Med 1998; 92:283-8. [CrossRef] 
9. Devouassoux G, Levy P, Rossini E, Pin I, Fior-Gozlan M, Henry $M$, et al. Sleep apnea is associated with bronchial inflammation and continuous positive airway pressureinduced airway hyperresponsiveness. J Allergy Clin Immunol 2007; 119:597-603. [CrossRef]

10. Lee KK, Birring SS. Cough and sleep. Lung 2010; 188 (Suppl 1):S91-4. [CrossRef]

11. Pratter MR, Brightling CE, Boulet LP, Irwin RS. An empiric integrative approach to the management of cough: ACCP evidence-based clinical practice guidelines. Chest 2006; 129:222S-31S. [CrossRef]
12. Larsson LG, Lundback $B$, Jonsson $A C$, Lindstrom $M$, Jonsson E. Symptoms related to snoring and sleep apnoea in subjects with chronic bronchitis: report from the Obstructive Lung Disease in Northern Sweden study. Respir Med 1997; 91:5-12. [CrossRef]

13. Chan KKY, Ing AJ, Laks L, Cossa G, Rogers P, Birring SS. Chronic cough in patients with sleep-disordered breathing. Eur Respir J 2010; 35:368-72. [CrossRef]

14. Ardıç S. Obstrüktif uyku apne sendromu ve inflamasyon. Turkiye Klinikleri J Int Med Sci 2007; 3:61-8. 